\title{
List of EU Regulations, Directives and Decisions
}

Note: Only instruments currently in force are listed below. Historically important documents are referenced fully in the footnotes of the main text.

Access Directive

Audiovisual Media Services (AVMS) Directive

Audiovisual Media Services (AVMS) Regulation (Proposed)
Directive 2002/19/EC of 7 March 2002 of the European Parliament and of the Council on access to, and interconnection of, electronic communications networks and associated facilities [2002] OJ L 108/7 ....... 49-51, 82-3, 103, 108, 113-16, 136-7, 164, 166-94, 196, 198, 230, 245-6, 272

Directive 2010/13/EU of the European Parliament and of the Council of 10 March 2010 on the coordination of certain provisions laid down by law, regulation or administrative action in Member States concerning the provision of audiovisual media services (codified version) [2010] OJ L 95/1 $69,253-7,265$

Proposal for a Directive of the European Parliament and of the Council amending Directive 2010/13/EU on the coordination of certain provisions laid down by law, regulation or administrative action in Member States concerning the provision of audiovisual media services in view of changing market realities, 25.5.2016, $\operatorname{COM}(2016) 287$ final $257-8$ 
Authorisation Directive

BEREC Regulation

BEREC Regulation (Proposed)

Better Regulation Directive

Broadband Cost Reduction Directive
Directive 2002/20/EC of the European Parliament and of the Council of 7 March 2002 on the authorisation of electronic communications networks and services [2002] OJ L 108/21 ...... 49-51, 82-3, 88, $116,132-3,135,139,142-5,154-6,157$, $167,169-71,174,204,211,244,250$

Regulation (EC) No. 1211/2009 of the European Parliament and of the Council of 25 November 2009 establishing the Body of European Regulators for Electronic Communications (BEREC) and the Office [2009] OJ L 337/1 59 , $77-80,89$

Proposal for a Regulation of the European Parliament and of the Council establishing the Body of European Regulators of Electronic Communications (BEREC), 14.9.2016, COM(2016) 591 final ....... 52, $59,77-80$

Directive 2009/140/EC of the European Parliament and of the Council of 25 November 2009 amending Directives 2002/21/EC on a common regulatory framework for electronic communications networks and services, 2002/19/EC on access to, and interconnection of, electronic communications networks and associated facilities, and 2002/20/EC on the authorisation of electronic communications networks and services, OJ L 337/37, 18.12.2009 $19,51,95,187$

Directive 2014/61/EU of the European Parliament and of the Council of 15 May 2014 on measures to reduce the cost of deploying high-speed electronic communications networks Text with EEA relevance, OJ L 155/1, 23.5.2014 ....... 58, 281, 283 
Citizens' Rights Directive

Competition Directive

‘Connected Continent' Proposal

Data Retention Directive (no longer in force)

Electronic Commerce Directive
Directive 2009/136/EC of the European Parliament and of the Council of 25 November 2009 amending Directive 2002/22/EC on universal service and users' rights relating to electronic communications networks and services, Directive 2002/58/EC concerning the processing of personal data and the protection of privacy in the electronic communications sector and Regulation (EC) No. 2006/2004 on cooperation between national authorities responsible for the enforcement of consumer protection laws, OJ L 337/11, 18.12.2009 51, 90, 201, 227

Commission Directive 2002/77/EC of 16 September 2002 on competition in the markets for electronic communications networks and services [2002] OJ L $249 / 1$ 43-4, 101-2, 251

Regulation of the European Parliament and of the Council laying down measures concerning the European single market for electronic communications and to achieve a Connected Continent, 11.9.2013

$\operatorname{COM}(2013) 627$ final $52-8,74,141$, $272-4$

Directive 2006/24/EC of the European Parliament and of the Council of 15 March 2006 on the retention of data generated or processed in communication with the provision of publicly available electronic communications services or of public communication networks and amending Directive 2002/58/EC [2006] OJ L $105 / 54$ 298-9, 306

Directive 2000/31/EC of the European Parliament and of the Council of 8 June 2000 on certain legal aspects of information society services, in particular electronic commerce, in the internal market [2000] OJ L 178/1 $45,68-9$, $137,160,162,265,297,308$ 
E-Privacy Directive (Directive on Privacy and Electronic Communications)

E-Privacy Regulation (Proposed)

European Electronic Communications Code (Proposed)
Directive 2002/58/EC of 12 July 2002 of the European Parliament and of the Council concerning the processing of personal data and the protection of privacy in the electronic communications sector [2002] OJ L201/37, 31 July 2002, amended by Directive 2009/136/EC [2009] OJ L 337/11, 18 November 2009 ... 49-51, 58, 89-90, 201, 227, 287, 293-301

Proposal for a Regulation Concerning the Respect for Private Life and the Protection of Personal Data in Electronic Communications and Repealing Directive 2002/58/EC (Regulation on Privacy and Electronic Communications), 10.1.2017 $\operatorname{COM}(2017) 10$ final $58,300-310$

Proposal for a Directive of the European Parliament and of the Council Establishing the European Electronic Communications Code (Recast), 14.9.2016 COM(2016) 590 final ......... 8-9, 17, 19, 29, 30, 32, 36, 50, $55-60,62,66,73,75,77,78,80,81$, 88-92, 96, 110, 130, 132, 141-2, 146, 151-9, 161-2, 164, 170, 173, 186, 190-91, 196, 202, 206-8, 214-18, 220-22, 224, 231-3, 236, 245, 249, 251-2, 266-8, 283-5, 302-4, 309-10, $315,317-18$

Framework Directive

Directive 2002/21/EC of the European Parliament and of the Council of 7 March 2002 on a common regulatory framework for electronic communications networks and services [2002] OJ L 108/33 _..... 2, 7, $15-17,19,22,36,42,46,49-50,51,59$, $69,75-6,78,81-7,89,98,104-9$, 112-16, 136-8, 143-7, 150-51, 155, 170, $172,174-5,178,182,184-5,189-90$, 199, 203, 207, 244-7, 249, 254-5, 265, $272,275,310-11,313-15$ 
General Data Protection Regulation (GDPR)

Merger Regulation

Notice on the Definition of the Relevant Market

'Open Internet’ Regulation

Radio Spectrum Decision

Radio Spectrum decisions harmonising technical conditions for the availability and efficient use

Radio Spectrum Policy Group Decision
Regulation (EU) 679/2016 of the European Parliament and of the Council of 27 April 2016 on the protection of natural persons with regard to the processing of personal data and on the free movement of such data, and repealing Directive 95/46/EC [2016] OJ L 119/1 _...... 288, 290, 292-3, 301-3, 305-9

Council Regulation (EC) No. 139/2004 of 20 January 2004 on the control of concentrations between undertakings (the EC Merger Regulation) [2004] OJ L $134 / 1$ $115-18,121,128$

Commission Notice on the Definition of Relevant Market for the Purposes of Community Competition Law, OJ C 372/5, 9.12.1997

Regulation (EU) 2015/2120 of the European Parliament and of the Council of 25 November 2015 laying down measures concerning open internet access and amending Directive 2002/22/EC on universal service and users' rights relating to electronic communications networks and services and Regulation (EU) No. $531 / 2012$ on roaming on public mobile communications networks within the Union [2015] OJ L 310 ... 79, 160, 201-2, $219,233,277,304$

Decision No. 676/2002/EC of the European Parliament and of the Council of 7 March 2002 on a regulatory framework for radio spectrum policy in the European Community, OJ L 108/1, 24.4.2002 $50,58,147$

Can be found on the Commission's website: https://ec.europa.eu/digital-singlemarket/news/radio-spectrum-decisions

Commission Decision 2002/622/EC of 26 July 2002 establishing a Radio Spectrum Policy Group \[2002] OJ L 198/49 ..... 49, $58,150-51$ 
Radio Spectrum Policy Programme

Radio Spectrum Policy Group (RSPG) Decision

Recommendation on relevant markets

Roaming Regulation (Recast)

Satellite and Cable Directive

SMP Guidelines
Decision No. 243/2012/EU of the European Parliament and of the Council of 14 March 2012 establishing a multiannual radio spectrum policy programme, OJ L 81/7, 21.3.2012 ...... 58,

Commission Decision of 16 December 2009 amending Decision 2002/622/EC establishing a Radio Spectrum Policy Group, OJ L 336/50, 18.12.2009 ... 49, 58, 150-51

Commission Recommendation of 9 October 2014 on relevant product and service markets within the electronic communications sector susceptible to ex ante regulation in accordance with Directive 2002/21/EC of the European Parliament and of the Council on a common regulatory framework for electronic communications networks and services, OJ L 295/79, 11.10.2014 $104-12$

See also the accompanying Explanatory Note to the Recommendation on relevant markets, 9.10.2014 SWD(2014) 298

Regulation (EU) No. 531/2012 of the European Parliament and of the Council of 13 June 2012 on roaming on public mobile communications networks within the Union (recast) [2012] OJ L $172 / 10$ 79-80, 218-19, 233, 275

Council Directive 93/83/EEC of 27 September 1993 on the coordination of certain rules concerning copyright and rights related to copyright applicable to satellite broadcasting and cable retransmission, OJ L 248, 6.10 .1993 259-62

Commission guidelines on market analysis and the assessment of significant market power under the Community regulatory framework for electronic communications networks and services, OJ C 165/6, 11.7.2002 $19,105-13,116$ 
Universal Service Directive
Directive 2002/22/EC of the European Parliament and of the Council of 7 March 2002 on universal service and users' rights relating to electronic communications networks and services [2002] OJ L $108 / 51$ 49-51, 79, 83, 115, 199-214, $219,227,233,274$ 
Andrej Savin - 9781786431806 Downloaded from PubFactory at 04/26/2023 09:0०: 4 AM via free access 